\title{
Assessment of Dietary Habits and Nutritional Status of Women of Childbearing Age in Cameroon: A Cross Sectional Study
}

\author{
Christelle Momdjo M’bobda1 ${ }^{1}$ Judith Laure Ngondi ${ }^{1}$, Françoise Raïssa Ntentie ${ }^{1,2}$, \\ Boris Ronald Tonou Tchuente ${ }^{1,3}$, Maxwell Wandji Nguedjo1,3, Boris Gabin Kingue Azantsa ${ }^{1 *}$, \\ Julius Enyong Oben ${ }^{1}$
}

${ }^{1}$ Laboratory of Nutrition and Nutritional Biochemistry, Department of Biochemistry, Faculty of Science, University of Yaoundé I, Yaounde, Cameroon

${ }^{2}$ Higher Teacher's and Training College, University of Maroua, Maroua, Cameroon

${ }^{3}$ Centre for Food and Nutrition Research, IMPM, Ministry of Scientific Research and Innovation, Yaounde, Cameroon

Email: *borisazantsa@yahoo.fr

How to cite this paper: M'bobda, C.M., Ngondi, J.L., Ntentie, F.R., Tchuente, B.R.T., Nguedjo, M.W., Azantsa, B.G.K. and Oben, J.E. (2020) Assessment of Dietary Habits and Nutritional Status of Women of Childbearing Age in Cameroon: A Cross Sectional Study. Open Journal of Epidemiology, 10, 369-392.

https://doi.org/10.4236/ojepi.2020.104030

Received: July 8, 2020

Accepted: October 20, 2020

Published: October 23, 2020

Copyright $\odot 2020$ by author(s) and Scientific Research Publishing Inc. This work is licensed under the Creative Commons Attribution International License (CC BY 4.0).

http://creativecommons.org/licenses/by/4.0/

(c) (i) Open Access

\begin{abstract}
Background: Malnutrition due to poor feeding habits, is still a serious public health issue in Cameroon. The objective of this study was to assess the dietary patterns and nutritional status of women of childbearing age in various geographical settings in Cameroon so as to propose intervention strategies. Methods: In a cross sectional study conducted from January 2014 to August 2015, women aged 14 - 49 years were randomly selected from the capital city Yaounde and four regions of Cameroon. Anthropometric measures were collected for nutritional status assessment. Data on diet habits and socio-demographic parameters were collected. Results: 608 women of reproductive age with average age $34.68 \pm 0.39$ years made up the study. Dietary patterns assessment revealed that, most study participants had a frequent intake of carbohydrate rich foods and fats and oils rich foods; but an infrequent intake of protein rich foods and vitamin and minerals rich foods in a week. Nutritional status assessment revealed that, $2.1 \%$ were underweight, $28.6 \%$ had a normal weight, $30.8 \%$ overweight, and $38.5 \%$ obese. The grass field regions presented the highest prevalence of underweight, overweight and obesity. Higher malnutrition levels were linked to low intakes of pulses and beans; milk and dairy products; vegetables and fruits food groups. Conclusion: Women of the study population had an unhealthy dietary pattern and a poor nutritional status. Therefore, strategies such as nutritional education are warranted and should be age and region specific, so as to target specific groups of women and ensure adequate nutritional status and health.
\end{abstract}




\section{Keywords}

Diet Pattern, Nutritional Status, Childbearing Age, Women, Cameroon

\section{Introduction}

Maternal nutrition status prior to conception is believed to affect embryonic and fetal growth [1]; and pre-pregnancy weight is a common indicator of a woman's nutritional status. Under nutrition in women contributes to $20 \%$ of maternal deaths [2]. Pre-pregnancy under nutrition, has been stated to lead to an increased risk of fetal loss, preterm birth, anemia, infections, fetal growth restriction (FGR), birth defects, low birth weight (BW), brain damage, admission to neonatal intensive care unit, and a longer duration of hospital stay, signs of the metabolic syndrome accompanied the catch-up in body weight and central adiposity [3]. A child's future nutrition status is affected before conception and is greatly dependent on the mother's nutrition status prior to, and during pregnancy [4]. Globally, maternal under nutrition and its consequences is estimated to account for 3.1 million child deaths annually [5]. In Africa, the lowest rates of underweight among women are found in Benin, Cameroon, Ghana, Lesotho, Rwanda, Swaziland and Togo [6]. Studies have found associations between dietary patterns and health outcomes and biomarkers, including the body mass index (BMI) [7]. Cohort studies have suggested that healthy dietary patterns up to 3 years before pregnancy resulted in a healthy pregnancy and pregnancy outcomes. In these studies, healthy dietary patterns are characterized by high intake of fruits, vegetables, legumes, nuts, and fish, and low intake of red and processed meat [5]. The need for maintaining optimal food habits throughout a woman's lifetime is essential to optimize her health and that of her offspring [8]. Women of reproductive age have the same dietary requirements as the general population [9]. In order to meet dietary guidelines, women of childbearing age should restrict simple carbohydrates while complex carbohydrates in the form of starches, legumes, seeds and bread should be limited to reasonable quantities. Useful protein sources can be meat, fish, cheese and dairy products (source of calcium), supplemented with small amounts of butter and vegetable fats [10]. Women of reproductive age, especially those who are planning a pregnancy, should be counseled to consume a well-balanced diet including fruits and vegetables, calcium rich foods, and protein-containing foods daily and increase their consumption of iron-rich or iron-fortified foods in conjunction with vitamin C-rich foods to enhance iron absorption [10]. In Cameroon, to our knowledge, few or no studies have assessed the dietary patterns of women of childbearing. Studies have been published on the dietary intakes of adolescent girls [11] [12] and women of childbearing age [13] in Cameroon. Therefore, with the increasing prevalence of obesity among women of childbearing age in Cameroon [14], it was therefore important to carry out this study which aimed at assessing the 
preconception dietary consumption patterns, nutritional status and determinants of dietary patterns and nutritional status of childbearing age women in Cameroon. This is in order to provide adequate dietary advices in preconception specific to these groups of Cameroonian women, so as to prevent malnutrition; and adverse malnutrition pre-pregnancy and pregnancy outcomes.

\section{Materials and Methods}

\subsection{Study Design and Setting Population}

In a cross-sectional study conducted from January 2014 to August 2015, women of childbearing age randomly selected during mass health campaigns on nutritional and cardio-metabolic risk factors surveys residing in the selected areas made up the study population. The selected areas include: the political capital of the country (Yaounde), the Littoral, the Western, North-West and Far-North Regions of the country. From the western region, Bafoussam the capital city, Mbouda town-the chief place of the Bamboutos division; Babadjou, a village situated about $12 \mathrm{~km}$ of Mbouda; Dschang town located in the Menoua department; Foumban located in the Noun department; Bafou village situated in the Menoua division made up the study sites from this region. The far-north region was equally included, and from this region, its headquarters Maroua served as study area. The littoral region another region which made up the study setting had as study sites Nkongsamba a city located in the Mungo department and Ekangte a nearby village of Nkongsamba made up the study area. The last region for this study was the northwest region. The study sites from this region included Wum, Mbengwi, Ndu towns and Nyen village [15].

\subsection{Inclusion and Exclusion Criteria}

Eligible participants were Cameroonian-born women of childbearing age, aged 14 - 49 years who lived in the study areas for at least 6 months and who gave their informed consent. Pregnant or lactating women, those taking dietary supplements as well as physically and mentally disabled women were excluded from the study.

\subsection{Sampling Procedure}

The sample size was calculated based on the formula for basic sample size calculation for random sampling [16] [17]. The 95\% confidence level, 5\% margin of error and $82 \%$ prevalence of low adjusted plasma zinc concentration among women of childbearing age in Cameroon [13] were used. 480 subjects were required for the minimum sample size, but 608 women were included in the study to allow for precision. A multiple-stage sampling which was divided into three stages was adopted for the survey. In the first stage, regions were selected, in the second stage, cities, towns and villages were selected and in the third stage, women of childbearing age were targeted in various public gatherings in various study sites from which approbations were received. In addition to the region, 
towns and villages randomly selected for this study, secondary data from other regions, towns and villages selected were used. In the first stage of the sampling, 3 regions (West, Littoral and Far-North) included in the previous health campaign were chosen. In addition to these, the North West region was randomly selected from the other seven regions of Cameroon using simple random sampling method (balloting) making a total of four regions retained. In the second stage consisting in randomly choosing cities, towns, little towns and villages; a big city (Bafoussam) was chosen at random from the 4 regions above and the political capital of the country (Yaounde) was also included. Four towns from the abovementioned regions which were randomly selected during the previous health campaign were also retained for this study and they were: Nkongsamba (littoral region), Maroua (far-north region), Dschang and Foumban (West Region). Three little towns: Mbengwi, Ndu, Wum were randomly selected from the North West region and one other town: Mbouda was selected from the west region. In addition, three villages selected during a previous campaign and proximate to three of the four little towns of the previous campaign were retained (Bafou, Bafolé, and Njimom). Two other villages were randomly selected during this study. They were Nyen which is proximate to Mbengwi in the North West region and Babadjou which is proximate to Mbouda in the west region. In the third stage, in each area retained or randomly selected, five quarters were randomly selected making a total of 65 quarters. In each of these 65 quarters, announcements and posters stating the purpose, the exact period and time of the study were read and pasted in churches, in general assemblies of various groups, in secondary schools, high schools, universities and all other places where women of childbearing age could be found. All women of childbearing age who met the inclusion criteria and gave their written consent were selected. A written consent was obtained from the parent or guardian of women younger than 21 years.

\subsection{Research Instruments: Questionnaires for Data Gathering}

Well-structured questionnaires were administered by well-trained health personnel. A questionnaire was conceived from the WHO STEPWISE questionnaire [18] to collect data on the identity (age, gender), the area or region of residence, the marital status, profession and educational level. Data collection was done through a face to face interview in data collections sites (health districts, health centers, churches, palace place ...). French, English and the local dialect were the languages used.

\subsection{Dietary Habits}

\section{Food frequency for each food group}

Dietary habits were assessed by collecting information on the frequency of consumption of various food groups using a food frequency questionnaire (FFQ). The FFQ included various food items consumed throughout the year 
(traditional diets; imported cereals and locally made cereals, tubers, meat, fish, eggs, poultry; dairy products, fruits, vegetables; fats and oils; snacks, beverages; alcoholic drinks; sweet drinks; tea ...) [19]. The questionnaire was designed to capture all foods/beverages typically consumed, including traditional foods not available in stores and those available seasonally. Data were collected on the number of days in the last 7 days a participant ate specific food items. The various foods were then grouped into eight food items (cereals and tubers group; pulses and beans group; milk and dairy products group; meat, fish and egg group; vegetable group; fruit group; oil group; sugar and derivative group) [20]. These information were used to calculate the food frequency for each of the eight food items consumed in the last seven days for each participant and for the study population. All the consumption frequencies of food items of the same group were summed, and the value of each group above 7 was recorded as 7 . Data on the frequency of consumption in a week of each food group were used to categorize each of the eight food group intake into three; Low. for food group intake 1 - 2 times per week; Moderate: for food group intake 3 - 4 times/week and High: for food group intake 5 - 7 times/week. The eight food groups obtained were further grouped into three food groups depending on their specific nutrient densities. These included carbohydrate and proteins rich foods, vitamins and minerals rich foods, fats and oils, and sugars rich foods.

\section{Frequency of traditional diets in a week}

Data on the frequency of intake of traditional diets in a week were also used to categorize traditional diets intake into three: Low intake: for 0 - 1 time per week; moderate intake: for intake 2 - 4 times per week and high intake: for 5 - 7 times per week

\subsection{Anthropometric Parameters}

The weight was recorded to the nearest $0.1 \mathrm{~kg}$ using an electronic balance (The Tanita $^{\text {tm }}$ BC-418 Segmental Body Composition Analyzer/Scale) with participants wearing light clothing. Height was measured with a Harpended ${ }^{\text {tw }}$ stadiometer to the nearest $0.1 \mathrm{~cm}$. Body Mass Index (BMI) was calculated by the formula BMI = Weight $(\mathrm{kg}) / \mathrm{Height}^{2}(\mathrm{~m})$ and expressed as $\mathrm{kg} / \mathrm{m}^{2}$. BMI was categorized as follows [21]: underweight: $\mathrm{BMI}<18.5 \mathrm{~kg} / \mathrm{m}^{2}$; normal weight: $\mathrm{BMI}=18.5-24.9$ $\mathrm{kg} / \mathrm{m}^{2}$; overweight: $\mathrm{BMI}=25.0-29.9 \mathrm{~kg} / \mathrm{m}^{2}$; obese: $\mathrm{BMI} \geq 30.0 \mathrm{~kg} / \mathrm{m}^{2}$.

\subsection{Ethical Consideration}

This study was approved by the National Ethic Committee of Research for $\mathrm{Hu}-$ man Health of Cameroon ( ${ }^{\circ}$ 2014/08/488/CE/CNERSH/SP). Authorizations were obtained from local and administrative authorities of each area of the capital city and four regions. Written consent was obtained from each woman who agreed to participate. Also, the parent or the guardian of each adolescent girl gave his/her consent for the child to participate in the study. Consents were obtained after the objectives, the minimal risks and benefits of the study were well 
explained. To ensure the confidentiality of the collected data, codes were attributed to each participant and no name was revealed. All participants received their results individually and nutritional advices were given to each subject with respect to her nutritional state upon completion of the study measurements.

\subsection{Statistical Analysis}

Data were analyzed using the IBM SPSS statistical software package version 20.0. Results are expressed as means with standard error of the mean for continuous variables, or as percentages for categorical variables. Categorical variables were compared by the Chi square test and continuous variables compared by one way analysis of variance (ANOVA) followed by post hoc LSD. Regression analyses were performed to evaluate risk. The level of statistical significance was $\mathrm{P}<0.05$.

\section{Results}

\subsection{Characteristics of the Study Population}

Overall 1152 women of childbearing age were recruited for the study among which, 996 gave their consent after been explained the objectives of the study. 157 participants did not completely fill the questionnaires due to lack of patience or lack of interest in the study during the study course or lack of time, making a total of 839 participants who completely filled the questionnaires. Of the 839 participants, 231 of them had missing anthropometric measures and other important parameters, making a total of 608 with all the parameters required for this study and were therefore included in this study and the final analysis. The average age of the sample population was $34.68 \pm 0.39$ years. An analysis of socio-demographic data revealed that participants in the 31 - 40 years age group represented $34.4 \%$ of the study population. The North West region represented the highest number of participants (36\%) of the study population. 24.3 percent of the participants of the study had a primary educational level. Up to 38.3 percent of the women of the study were housewives and most of them $(70.6 \%$ in the 95\% CI) were married (Table 1).

\subsection{Dietary Patterns of the Population}

Concerning the consumption of foods rich in carbohydrate, proteins, vitamins and minerals, fats and oils and sugars in a week, most participants (86.4\%) of the study consumed cereals and tubers food groups 5 to 7 times in a week while $4.2 \%$ consumed this food group 1 to 2 times a week in the $95 \%$ confidence interval (CI). With regards to protein rich foods such as the pulse food group, up to $41.6 \%$ had a low intake ( 1 to 2 times in a week) while only $24.3 \%$ of the women had a high intake in a week. While, most of the women (57\%) had a low intake of milk and dairy products food group in a week. Also, the meat, fish and egg group was consumed only 1 to 2 times in a week by up to $43.8 \%$ of the women while only $27.3 \%$ of them in the $95 \%$ CI had a high intake in a week. With regards to vitamins and minerals rich foods, the vegetable food group and 
Table 1. Distribution of study population by socio-demographic parameters.

\begin{tabular}{|c|c|c|c|c|}
\hline \multirow{2}{*}{ Characteristics } & \multirow{2}{*}{$\begin{array}{l}\text { Frequency } \\
(\mathrm{N})\end{array}$} & \multirow{2}{*}{$\begin{array}{l}\text { Percentage } \\
(\%)\end{array}$} & \multicolumn{2}{|c|}{ 95\% Confidence Interval } \\
\hline & & & Lower & Upper \\
\hline \multicolumn{5}{|l|}{ Age group } \\
\hline $14-20$ years & 63 & 10.4 & 8.1 & 12.8 \\
\hline 21 - 30 years & 141 & 23.2 & 19.7 & 26.8 \\
\hline 31 - 40 years & 209 & 34.4 & 30.3 & 38.1 \\
\hline 41 - 49 years & 195 & 32.1 & 28.1 & 36.0 \\
\hline \multicolumn{5}{|l|}{ Area of residence } \\
\hline Yaoundé & 72 & 11.8 & 9.2 & 14.6 \\
\hline Littoral & 119 & 19.6 & 16.4 & 23.2 \\
\hline West & 172 & 28.3 & 24.8 & 32.1 \\
\hline North west & 219 & 36.0 & 31.9 & 39.8 \\
\hline Far North & 26 & 4.3 & 2.6 & 5.9 \\
\hline \multicolumn{5}{|l|}{ Educational level } \\
\hline Illiterate & 121 & 19.9 & 16.6 & 23.0 \\
\hline Literates & 89 & 14.6 & 11.7 & 17.4 \\
\hline Primary & 148 & 24.3 & 20.9 & 27.8 \\
\hline First cycle & 117 & 19.2 & 16.3 & 22.4 \\
\hline Second cycle & 116 & 19.1 & 16.0 & 22.4 \\
\hline University & 17 & 2.8 & 1.5 & 4.1 \\
\hline \multicolumn{5}{|l|}{ Profession } \\
\hline Student & 106 & 18.1 & 15.0 & 21.2 \\
\hline Employed & 93 & 15.9 & 12.8 & 18.8 \\
\hline Odd jobs/farmers & 110 & 18.8 & 15.7 & 21.9 \\
\hline Business & 52 & 8.9 & 6.7 & 11.4 \\
\hline Housewives & 247 & 38.3 & 34.2 & 42.2 \\
\hline \multicolumn{5}{|l|}{ Marital Status } \\
\hline Single & 74 & 12.2 & 9.5 & 14.6 \\
\hline Married & 429 & 70.6 & 66.9 & 74.2 \\
\hline Widow/Divorced & 105 & 17.3 & 14.3 & 20.4 \\
\hline
\end{tabular}

the fruits group were taken 5 to 7 times in a week by $33.1 \%$ and $9.8 \%$ of the participants respectively (Table 2). The fats and oils group was eaten 5 to 7 times in a week by most women (56.9\%) while sugar rich foods (sugar food group) was taken only 1 to 2 times in a week by most women $(57.2 \%)$ in the $95 \%$ CI (Table 2).

\subsection{Consumption Frequency of Various Food Groups by Age Group}

The frequency of consumption of various food groups by age group is shown in Table 3. It can be seen that, a high intake of carbohydrate rich food was mostly observe among the 31 - 40 years age group (28.7\%) followed by the $41-49$ years age group $(26.9 \%)$, although there was no significant difference $(p>0.05)$. A 
moderate intake was mostly observed equally among the 31 - 40 years age group. A low intake of carbohydrate rich foods was mostly observed among the $41-49$ years age group $(1.6 \%)(\mathrm{p}>0.05)$. A high intake $(5-7$ times in a week) of protein rich foods was mostly observed among participants of the 31 - 40 years age group. $7.9 \%$ of the participants in this age group had a high intake of for pulses, $8.0 \%$ of them had a high intake of milk and dairy products $(\mathrm{p}<0.05)$ and $8.8 \%$ of them had a high intake of meat, fish and egg food group ( $p>0.05)$. Whereas, a low intake of this food category was mostly observed among the 41-49 years age group $(19 \%$ for milk and dairy products $(\mathrm{p}<0.05)$ and $14 \%$ for meat, fish and egg food group $(\mathrm{p}>0.05))$. The study of the frequency of consumption of vitamins and minerals rich foods revealed that, the 31 - 40 years age group (12.6\% for vegetable intake and $21.0 \%$ for fruits intake) presented the highest percentage of participants with a low intake of this food category followed by the 41 - 49 years age group (12.4\% for vegetable intake and $17.4 \%$ for fruits intake). With regards to the intake of fats and oils food group, the 31 - 40 years age group showed the highest percentage of low intake (9.7\%) although there was no significant difference compared to other age group ( $p>0.05)$. The $31-40$ year age group recorded the highest percentage $(7.5 \%)$ of a high intake of sugar food items compared to the other age groups $(\mathrm{p}<0.05)$.

Table 2. Frequency of consumption of Carbohydrate, proteins, minerals and vitamins, lipid and sugar rich foods in the study population.

\begin{tabular}{|c|c|c|c|}
\hline Food groups $(\mathrm{N}=608)$ & $\begin{array}{c}\text { Low intake } \\
\text { (1- } 2 \text { times/week) } \\
\%(95 \% \mathrm{CI})\end{array}$ & $\begin{array}{c}\text { Moderate intake } \\
\text { (3 - } 4 \text { times/week) } \\
\%(95 \% \mathrm{CI})\end{array}$ & $\begin{array}{c}\text { High intake } \\
\text { (5 - } 7 \text { times/week) } \\
\%(95 \% \mathrm{CI})\end{array}$ \\
\hline \multicolumn{4}{|c|}{ Carbohydrate and proteins rich foods } \\
\hline $\begin{array}{c}\text { Cereals and tubers } \\
\text { (Carbohydrate rich foods) }\end{array}$ & $4.2(2.4-5.9)$ & $9.5(7.1-12.1)$ & $86.4(83.4-89.3)$ \\
\hline $\begin{array}{c}\text { Pulses } \\
\text { (Protein rich foods) }\end{array}$ & $41.6(37.2-46.3)$ & $34.1(30.0-38.9)$ & $24.3(20.4-28.2)$ \\
\hline $\begin{array}{l}\text { Milk and Dairy products } \\
\text { (Protein rich foods) }\end{array}$ & $57.0(46.0-67.0)$ & $27.0(18.0-36.0)$ & $16.0(10.0-23.8)$ \\
\hline $\begin{array}{l}\text { Meat, fish and eggs } \\
\text { (Protein rich foods) }\end{array}$ & $43.8(38.3-49.3)$ & $28.9(23.7-34.0)$ & $27.3(22.4-32.5)$ \\
\hline \multicolumn{4}{|c|}{ Vitamins and Minerals rich foods } \\
\hline Vegetables & $38.5(34.0-42.9)$ & $28.4(24.5-32.6)$ & $33.1(28.7-37.3)$ \\
\hline Fruits & $69.2(62.5-75.0)$ & $21.0(15.7-25.9)$ & $9.8(6.3-14.2)$ \\
\hline \multicolumn{4}{|c|}{ Lipids and sugars rich foods } \\
\hline $\begin{array}{l}\text { Fats and oils } \\
\text { (lipids rich foods) }\end{array}$ & $32.3(27.1-37.8)$ & $10.8(7.3-14.5)$ & $56.9(51.4-62.8)$ \\
\hline $\begin{array}{c}\text { Sugar } \\
\text { (sugar rich foods) }\end{array}$ & $57.2(51.7-62.9)$ & $22.1(17.8-26.7)$ & $20.7(17.0-25.0)$ \\
\hline
\end{tabular}

$\%$ : percentage; CI: Confidence Interval. 
Table 3. Frequency of consumption of Carbohydrate, proteins, minerals and vitamins, lipid and sugar rich foods in the study population by age group.

\begin{tabular}{|c|c|c|c|c|c|}
\hline $\begin{array}{l}\text { Age groups } \\
\text { Food groups }\end{array}$ & $\begin{array}{l}14-20 \\
\text { years }\end{array}$ & $\begin{array}{l}21-30 \\
\text { years }\end{array}$ & $\begin{array}{c}31-40 \\
\text { years }\end{array}$ & $\begin{array}{l}41-49 \\
\text { years }\end{array}$ & P-Value \\
\hline \multicolumn{6}{|c|}{ Carbohydrate rich foods } \\
\hline \multicolumn{6}{|l|}{ Cereals and tubers } \\
\hline (1 - 2 times/week) & $5(1.0)$ & $3(0.6)$ & $5(1.0)$ & $8(1.6)$ & \multirow{3}{*}{0.441} \\
\hline (3- 4 times/week) & $4(0.8)$ & $14(2.8)$ & $17(3.4)$ & $13(2.6)$ & \\
\hline \multirow[t]{2}{*}{ (5 - 7 times/week) } & $48(9.5)$ & $108(21.3)$ & $145(28.7)$ & $136(26.9)$ & \\
\hline & \multicolumn{5}{|c|}{ Proteins rich foods } \\
\hline \multicolumn{6}{|l|}{ Pulses } \\
\hline (1 - 2 times/week) & $22(4.8)$ & 49 (10.7) & $64(14.0)$ & $55(12.0)$ & \multirow{3}{*}{0.851} \\
\hline (3- 4 times/week) & $15(3.3)$ & $36(7.9)$ & $48(10.5)$ & $57(12.5)$ & \\
\hline (5 - 7 times/week) & $14(3.1)$ & $26(5.7)$ & $36(7.9)$ & $35(7.7)$ & \\
\hline \multicolumn{6}{|l|}{ Milk and Dairy products } \\
\hline (1 - 2 times/week) & $11(11.0)$ & $17(17.0)$ & $10(10.0)$ & $19(19.0)$ & \multirow{3}{*}{0.046} \\
\hline (3 - 4 times/week) & $4(4.0)$ & $7(7.0)$ & $5(5.0)$ & $11(11.0)$ & \\
\hline (5 - 7 times/week) & $5(5.0)$ & $1(1.0)$ & $8(8.0)$ & $2(2.0)$ & \\
\hline \multicolumn{6}{|l|}{ Meat, fish and eggs } \\
\hline (1 - 2 times/week) & $13(4.2)$ & $42(13,6)$ & $37(12,0)$ & $43(14.0)$ & \multirow{3}{*}{0.153} \\
\hline (3- 4 times/week) & $8(2.6)$ & $23(7.5)$ & $27(8.8)$ & $31(10.1)$ & \\
\hline (5 - 7 times/week) & $17(5.5)$ & $17(5.5)$ & $27(8.8)$ & $23(7.5)$ & \\
\hline \multicolumn{6}{|c|}{ Vitamins and Minerals rich foods } \\
\hline \multicolumn{6}{|l|}{ Vegetables } \\
\hline (1 - 2 times/week) & $15(3.5)$ & $43(10.0)$ & $54(12.6)$ & $53(12.4)$ & \multirow{3}{*}{0.926} \\
\hline (3 - 4 times/week) & $16(3.7)$ & $32(7.5)$ & $37(8.6)$ & $37(8.6)$ & \\
\hline (5 - 7 times/week) & $15(3,5)$ & $33(7.7)$ & $50(11.7)$ & $44(10.3)$ & \\
\hline \multicolumn{6}{|l|}{ Fruits } \\
\hline (1 - 2 times/week) & $26(11.6)$ & $43(19.2)$ & $47(21.0)$ & $39(17.4)$ & \multirow{3}{*}{0.453} \\
\hline (3 - 4 times/week) & $4(1.8)$ & $10(4.5)$ & $18(8.0)$ & $15(6.7)$ & \\
\hline (5 - 7 times/week) & $2(0.9)$ & $5(2.2)$ & $6(2.7)$ & $9(4.0)$ & \\
\hline \multicolumn{6}{|c|}{ Fats and oils and sugars rich foods } \\
\hline \multicolumn{6}{|l|}{ Fats and oils } \\
\hline (1 - 2 times/week) & $13(4.5)$ & $25(8.7)$ & $28(9.7)$ & $27(9.4)$ & \multirow{3}{*}{0.895} \\
\hline (3 - 4 times/week) & $2(0.7)$ & $10(3.5)$ & $9(3.1)$ & $10(3.5)$ & \\
\hline (5 - 7 times/week) & $26(9.0)$ & $41(14.2)$ & $48(16.7)$ & $49(17.0)$ & \\
\hline \multicolumn{6}{|l|}{ Sugar } \\
\hline (1 - 2 times/week) & $18(5.2)$ & $56(16.1)$ & $55(15.8)$ & $70(20.1)$ & \multirow{3}{*}{0.003} \\
\hline (3- 4 times/week) & $7(2.0)$ & $25(7.2)$ & $26(7.5)$ & $19(5.5)$ & \\
\hline (5 - 7 times/week) & $17(4.9)$ & $18(5.2)$ & $26(7.5)$ & $11(3.5)$ & \\
\hline
\end{tabular}

\subsection{Nutritional Status of the Study Population}

In the population, only $2.1 \%$ of the women were underweight but up to $30.8 \%$ of them were overweight and $38.5 \%$ were obese in the $95 \%$ confident interval (Table 4). The prevalence of underweight was highest among women in the 21 30 years age group $(0.8 \%)$ followed by those in the $41-49$ years age group $(0.7 \%)(p>0.05)$. While that of overweight was highest in the $31-40$ years age group (11.7\%) and this was significantly different across all the age groups $(\mathrm{p}<$ 0.05). Study participants in the $41-49$ years age group recorded the highest 
prevalence obesity $(16.1 \%)$. These differences were significant across all the age groups $(\mathrm{p}<0.05)($ Table 4$)$.

\subsection{Influence of Socio-Demographic Factors on the Nutritional Status of the Study Population}

The assessment of nutritional status with respect to some socio demographic factors revealed that, with respect to the region/area of residence, the prevalence of underweight, overweight and obesity were highest in the northwest region and these were: $69.2 \%$ for underweight, $33.7 \%$ for overweight and $26.5 \%$ for obesity ( $p<0.001)$. The western region recorded the next highest prevalence of all the forms of malnutrition and the differences in the rates were statistically significant $(\mathrm{p}<0.001)$. Overweight $(26.2 \%)$ and obesity $(27.4 \%)$ were highest among study participants with a primary education and these were statistically significant $(\mathrm{p}<0.001)$. Housewives and married women recorded the highest prevalence of underweight, overweight and obesity when the profession and the marital status were considered. The differences between the rates were statistically significant $(\mathrm{p}<0.001)$. All these results are shown in Table 5.

\subsection{Influence of Dietary Patterns on the Nutritional Status of the Study Population}

Nutritional status assessment in association to the frequency of intake of various food categories in a week as shown in Table 6 revealed that, a higher prevalence of underweight $(p<0.05)$, overweight and obesity $(p<0.001)$ were all associated to a high intake of cereals and tubers in a week. A low intake of pluses (beans, nuts ...) in a week whereas, was associated to a higher prevalence of obesity (42.6\%) $(\mathrm{p}<0.05)($ Table 6).

A low intake of protein rich foods such as milk and dairy products in a week was significantly associated to a higher rate of overweight $(58.3 \%)(\mathrm{p}<0.05)$. A low intake of meat, fish and egg food group was associated to a significantly higher rate of overweight $(44.8 \%)(\mathrm{p}<0.05)$. A higher prevalence of underweight, overweight and obesity was linked to a low intake of vegetables in a week although not statistically significant (Table 6). It was also observed that, a high intake of fats and oils (5 to 7 times) in a week was associated to a significantly higher prevalence of overweight (54.5\%) and obesity (63.2\%) compared to the other intake categories $(\mathrm{p}<0.001)$. Whereas a low intake of sugar foods $(1$ to 2 times) in a week was instead associated to a significantly higher prevalence of these forms of malnutrition (Table 6).

\subsection{Risk Factors Influencing Abnormal Weight Status among Women of Childbearing Age in Cameroon}

Socio-demographic risk factor assessment as shown in Table 7 revealed that women in the 31 - 40 years age group were 2.187 times at risk of becoming overweight in the $95 \%$ confident interval. Also, all the age groups were risk factors of developing obesity $\mathrm{p}<0.05$ in the $95 \%$ CI. Based on the region or area of 
residence, participants living the North West Region were 0.417 times less likely of becoming obese compared to those living in Yaounde $\mathrm{p}<0.05$ in the $95 \%$ CI. Risk assessment based on marital status showed that married women were 2.249 times more likely of becoming obese compared to single women, $\mathrm{p}<0.05$ in $95 \%$ CI. The educational level was not a risk factor of a poor nutritional status.

Table 4. Nutritional status of women of childbearing age in the overall population and by age group.

\begin{tabular}{ccccccc}
\hline $\begin{array}{c}\text { Age groups } \\
\text { Weight Status }\end{array}$ & $\begin{array}{c}\text { Overall } \\
\%(95 \% \mathrm{CI})\end{array}$ & $\begin{array}{c}14-20 \\
\text { Years }\end{array}$ & $\begin{array}{c}21-30 \\
\text { years }\end{array}$ & $\begin{array}{c}31-40 \\
\text { years }\end{array}$ & $\begin{array}{c}41-49 \\
\text { years }\end{array}$ & $\begin{array}{c}\text { P- } \\
\text { value }\end{array}$ \\
\hline $\begin{array}{c}\text { Underweight, } \mathrm{n}=13 \\
\left(\mathrm{BMI}<18.5 \mathrm{~kg} / \mathrm{m}^{2}\right)\end{array}$ & $2.1(1.2-3.5)$ & $2(0.3)$ & $5(0.8)$ & $2(0.3)$ & $4(0.7)$ & 0.557 \\
$\begin{array}{c}\text { Normal, } \mathrm{n}=174 \\
\left(\mathrm{BMI}=18.5-24.9 \mathrm{~kg} / \mathrm{m}^{2}\right)\end{array}$ & $28.6(25.2-31.7)$ & $43(7.1)$ & $54(8.9)$ & $45(7.4)$ & $32(5.3)$ & 0.001 \\
$\begin{array}{c}\text { Overweight, } \mathrm{n}=187 \\
\left(\mathrm{BMI} \geq 25 \mathrm{~kg} / \mathrm{m}^{2}\right)\end{array}$ & $30.8(27.1-34.5)$ & $12(2.0)$ & $43(7.1)$ & $71(11.7)$ & $61(10.0)$ & 0.001 \\
$\begin{array}{l}\text { Obesity, } \mathrm{n}=234 \\
\left(\mathrm{BMI} \geq 30 \mathrm{~kg} / \mathrm{m}^{2}\right)\end{array}$ & $38.5(35.0-42.4)$ & $6(1.0)$ & $39(6.4)$ & $91(15.0)$ & $98(16.1)$ & 0.001
\end{tabular}

CI: Confidence Interval; BMI: Body Mass Index; P-value Significant at p $<0.05$.

Table 5. Nutritional status with respect to socio-demographic parameters of the subjects.

\begin{tabular}{|c|c|c|c|c|}
\hline Parameters & $\begin{array}{l}\text { Underweight } \\
\text { Frequency (\%) }\end{array}$ & $\begin{array}{c}\text { Normal } \\
\text { Frequency (\%) }\end{array}$ & $\begin{array}{c}\text { Overweight } \\
\text { Frequency (\%) }\end{array}$ & $\begin{array}{c}\text { Obesity } \\
\text { Frequency (\%) }\end{array}$ \\
\hline Area of residence & $\mathrm{P}=0.018$ & $\mathrm{P}<0.001$ & $\mathrm{P}<0.001$ & $\mathrm{P}<0.001$ \\
\hline Yaoundé & $0(0.0)$ & $15(2.5)$ & $22(11.8)$ & $35(15.0)$ \\
\hline Littoral & $0(0.0)$ & $30(4.9)$ & $37(19.8)$ & $52(22.2)$ \\
\hline West & $3(23.1)$ & $34(5.6)$ & $57(30.5)$ & $78(33.3)$ \\
\hline North west & $9(69.2)$ & $85(14.0)$ & $63(33.7)$ & $62(26.5)$ \\
\hline North & $1(7.7)$ & $10(1.6)$ & $8(4.3)$ & $7(3.0)$ \\
\hline Educational level & $\mathrm{P}=0.846$ & $\mathrm{P}=0.093$ & $\mathrm{P}<0.001$ & $\mathrm{P}<0.001$ \\
\hline Illiterate & $3(23.1)$ & $32(5.3)$ & $35(18.7)$ & $51(21.8)$ \\
\hline Literates & $2(15.4)$ & $33(5.4)$ & $26(13.9)$ & $28(12.0)$ \\
\hline Primary & $4(30.8)$ & $31(5.1)$ & $49(26.2)$ & $64(27.4)$ \\
\hline First cycle & $4(30.8)$ & $40(6.6)$ & $37(19.8)$ & $36(15.4)$ \\
\hline Second cycle & $0(0.0)$ & $33(5.4)$ & $34(18.2)$ & $49(20.9)$ \\
\hline University & $0(0.0)$ & $5(0.8)$ & $6(3.2)$ & $6(2.6)$ \\
\hline Profession & $\mathrm{P}=0.123$ & $\mathrm{P}<0.001$ & $\mathrm{P}<0.001$ & $\mathrm{P}<0.001$ \\
\hline Student & $2(15.4)$ & $65(11.1)$ & $25(13.9)$ & $14(6.3)$ \\
\hline Employed & $2(15.4)$ & $6(1.0)$ & $37(20.6)$ & $48(21.5)$ \\
\hline Odd jobs/farmers & $2(15.4)$ & $39(6.7)$ & $32(17.8)$ & $37(16.6)$ \\
\hline Business & $0(0.0)$ & $8(1.4)$ & $17(9.4)$ & $27(12.1)$ \\
\hline Housewives & $7(53.8)$ & $51(8.7)$ & $69(38.3)$ & $97(43.5)$ \\
\hline Marital Status & $P=0.058$ & $\mathrm{P}=0.105$ & $\mathrm{P}<0.001$ & $\mathrm{P}<0.001$ \\
\hline Single & $1(7.7)$ & $26(4.3)$ & $29(15.5)$ & $18(7.7)$ \\
\hline Married & $8(61.5)$ & $112(18.4)$ & $129(69.0)$ & $180(76.9)$ \\
\hline Widow/Divorced & $4(30.8)$ & $36(5.9)$ & $29(15.5)$ & $36(15.4)$ \\
\hline
\end{tabular}


Table 6. Nutritional status with respect to frequency of intake of various food groups among women of childbearing age.

\begin{tabular}{|c|c|c|c|c|}
\hline Food groups & $\begin{array}{l}\text { Underweight } \\
\text { Frequency (\%) }\end{array}$ & $\begin{array}{c}\text { Normal } \\
\text { Frequency (\%) }\end{array}$ & $\begin{array}{c}\text { Overweight } \\
\text { Frequency (\%) }\end{array}$ & $\begin{array}{c}\text { Obesity } \\
\text { Frequency (\%) }\end{array}$ \\
\hline \multicolumn{5}{|c|}{ Carbohydrates rich foods } \\
\hline Cereals and tubers & $\mathrm{P}=0.002$ & $\mathrm{P}=0.614$ & $\mathrm{P}<0.001$ & $\mathrm{P}<0.001$ \\
\hline (1 - 2 times/week) & $1(7.7)$ & $8(1.6)$ & $4(2.6)$ & $8(4.2)$ \\
\hline (3 - 4 times/week) & $0(0.0)$ & $15(3.0)$ & $18(11.7)$ & $15(7.9)$ \\
\hline (5 - 7 times/week) & $12(92.3)$ & $125(24.7)$ & $132(85.7)$ & $168(88.0)$ \\
\hline \multicolumn{5}{|c|}{ Proteins rich foods } \\
\hline Pulses & $P=0.039$ & $\mathrm{P}=0.971$ & $\mathrm{P}=0.305$ & $\mathrm{P}=0.001$ \\
\hline (1 - 2 times/week) & $8(66.7)$ & $54(11.8)$ & $56(38.9)$ & $72(42.6)$ \\
\hline (3- 4 times/week) & $1(8.3)$ & $45(9.8)$ & $47(32.6)$ & $63(37.3)$ \\
\hline (5 - 7 times/week) & $3(25.0)$ & $33(7.2)$ & $41(28.5)$ & $34(20.1)$ \\
\hline \multicolumn{5}{|l|}{ Milk and Dairy } \\
\hline products & $\mathrm{P}=1$ & $\mathrm{P}=0.409$ & $\mathrm{P}=0.005$ & $\mathrm{P}=0.148$ \\
\hline (1 - 2 times/week) & $1(100.0)$ & $22(22.0)$ & $14(58.3)$ & $16(48.5)$ \\
\hline (3 - 4 times/week) & $0(0.0)$ & $8(8.0)$ & $9(37.5)$ & $10(30.3)$ \\
\hline (5 - 7 times/week) & $0(0.0)$ & $8(8.0)$ & $1(4.2)$ & $7(21.2)$ \\
\hline Meat, fish and eggs & $\mathrm{P}=0.097$ & $\mathrm{P}=0.555$ & $\mathrm{P}=0.040$ & $\mathrm{P}=0.132$ \\
\hline (1 - 2 times/week) & $1(11.1)$ & $45(14.6)$ & $43(44.8)$ & $46(41.8)$ \\
\hline (3- 4 times/week) & $6(66.7)$ & $24(7.8)$ & $30(31.2)$ & $29(26.4)$ \\
\hline (5 - 7 times/week) & $2(22.2)$ & $24(7.8)$ & $23(24.0)$ & $35(31.8)$ \\
\hline \multicolumn{5}{|c|}{ Vitamins and mineral rich foods } \\
\hline Vegetables & $P=0.670$ & $\mathrm{P}=0.735$ & $\mathrm{P}=0.461$ & $\mathrm{P}=0.077$ \\
\hline (1 - 2 times/week) & $4(40.0)$ & $47(11.0)$ & $51(38.3)$ & $63(40.4)$ \\
\hline (3 - 4 times/week) & $2(20.0)$ & $40(9.3)$ & $40(30.1)$ & $40(25.6)$ \\
\hline (5 - 7 times/week) & $4(40.0)$ & $43(10.0)$ & $42(31.6)$ & $53(34.0)$ \\
\hline Fruits & $\mathrm{P}=0.020$ & $\mathrm{P}=0.428$ & $\mathrm{P}<0.001$ & $\mathrm{P}<0.001$ \\
\hline (1 - 2 times/week) & $8(88.9)$ & $54(24.1)$ & $45(68.2)$ & $48(62.3)$ \\
\hline (3 - 4 times/week) & $0(0.0)$ & $12(5.4)$ & $18(27.3)$ & $17(22.1)$ \\
\hline (5 - 7 times/week) & $1(11.1)$ & $6(2.7)$ & $3(4.5)$ & $12(15.6)$ \\
\hline \multicolumn{5}{|c|}{ Fats and oils and sugar rich foods } \\
\hline Fats and oils & $\mathrm{P}=0.102$ & $\mathrm{P}=0.475$ & $\mathrm{P}<0.001$ & $\mathrm{P}<0.001$ \\
\hline (1 - 2 times/week) & $5(71.4)$ & $35(12.2)$ & $29(33.0)$ & $24(25.3)$ \\
\hline (3 - 4 times/week) & $1(14.3)$ & $8(2.8)$ & $11(12.5)$ & $11(11.6)$ \\
\hline (5 - 7 times/week) & $1(14.3)$ & $55(19.1)$ & $48(54.5)$ & $60(63.2)$ \\
\hline Sugar & $P=0.695$ & $\mathrm{P}=0.092$ & $\mathrm{P}=0.001$ & $\mathrm{P}<0.001$ \\
\hline (1 - 2 times/week) & $3(27.3)$ & $55(15.8)$ & $50(49.5)$ & $91(67.4)$ \\
\hline (3 - 4 times/week) & $5(45.5)$ & $18(5.2)$ & $32(31.7)$ & $22(16.3)$ \\
\hline (5 - 7 times/week) & $3(27.3)$ & $28(8.0)$ & $19(18.8)$ & $22(16.3)$ \\
\hline
\end{tabular}


Table 7. Socio-demographic risk factors of abnormal weight status (BMI) among women of Childbearing age in Cameroon.

\begin{tabular}{|c|c|c|c|}
\hline Risk factors & $\begin{array}{c}\text { Underweight } \\
\text { OR (CI 95\%) p-value }\end{array}$ & $\begin{array}{c}\text { Overweight } \\
\text { OR (CI 95\%) p-value }\end{array}$ & $\begin{array}{c}\text { Obesity } \\
\text { OR (CI } 95 \%) \text {-value }\end{array}$ \\
\hline \multicolumn{4}{|l|}{ Age group (Years) } \\
\hline $14-20$ & 1.0 & 1.0 & 1.0 \\
\hline $21-30$ & $0.893(0.168-4.725) p=0.893$ & $1.865(0.904-3.846) \mathrm{p}=0.092$ & $3.632(1.450-9.102) p=0.006$ \\
\hline $31-40$ & $3.393(0.468-4.594) \mathrm{p}=0.227$ & $2.187(1.096-4.364) \mathrm{p}=0.026$ & $7.326(3.025-17.743) \mathrm{p}<0.001$ \\
\hline $41-49$ & $1.566(0.280-8.758) \mathrm{p}=0.610$ & $1.935(0.963-3.888) \mathrm{p}=0.064$ & $9.568(3.954-23.298) \mathrm{p}<0.001$ \\
\hline \multicolumn{4}{|l|}{ Area of residence } \\
\hline Yaoundé & 1.0 & 1.0 & 1.0 \\
\hline Littoral & l & $1.025(0.544-1.933) \mathrm{p}=0.938$ & $0.820(0.456-1.476) \mathrm{p}=0.509$ \\
\hline West & l & $1.126(0.622-2.039) \mathrm{p}=0.694$ & $0.877(0.506-1.522) \mathrm{p}=0.641$ \\
\hline North west & l & $0.918(0.514-1.640) \mathrm{p}=0.772$ & $0.417(0.241-0.722) \mathrm{p}=0.002$ \\
\hline Far-North & l & $1.010(0.382-2.670) \mathrm{p}=0.984$ & $0.389(0.146-1.040) \mathrm{p}=0.060$ \\
\hline \multicolumn{4}{|l|}{ Educational Level } \\
\hline University & 1.0 & 1.0 & 1.0 \\
\hline Illiterate & l & $0.746(0.256-2.174) \mathrm{p}=0.591$ & $1.336(0.464-3.848) \mathrm{p}=0.592$ \\
\hline Literate & l & $0.757(0.253-2.261) \mathrm{p}=0.618$ & $0.842(0.283-2.505) \mathrm{p}=0.757$ \\
\hline Primary & I & $0.907(0.317-2.598) \mathrm{p}=0.856$ & $1.397(0.491-3.978) \mathrm{p}=0.531$ \\
\hline First cycle & l & $0.848(0.291-2.468) \mathrm{p}=0.762$ & $0.815(0.280-2.374) \mathrm{p}=0.707$ \\
\hline Second cycle & l & $0.760(0.260-2.221) \mathrm{p}=0.616$ & $1.341(0.464-3.873) \mathrm{p}=0.588$ \\
\hline \multicolumn{4}{|l|}{ Marital status } \\
\hline Single & & 1.0 & 1.0 \\
\hline Married & l & $0.667(0.401-1.111) \mathrm{p}=0.120$ & $2.249(1.279-3.955) p=0.005$ \\
\hline Widow/divorced & l & $0.592(0.314-1.115) \mathrm{p}=0.105$ & $1.623(0.833-3.161) p=0.154$ \\
\hline
\end{tabular}

OR: Odd Ratio; CI: Confidence Interval; significant at $\mathrm{p}<0.05$.

\section{Discussion}

The present work was undertaken to provide information on the dietary habits and nutritional status of women of childbearing age in Cameroon. The assessment of the dietary patterns of women of childbearing age of the study revealed that in a week, most women (more than 50\%) consumed cereals and tubers, and fats and oils food groups while a few of them had a high intake of vegetables, fruits, milk and dairy products, meat, fish and eggs and also pulses food groups in a week, suggesting an overall unhealthy food habit among most women of the study. Also, in general, in all the age groups, cereals and tubers food group, and fats and oils group were mostly consumed 5 to 7 times in a week. With regards to pulses intake, in all the age groups, beans and nuts food group were mostly eaten 1 to 2 times in a week. The same observation was made for protein rich foods groups such as milk and dairy products food group, meat, fish and egg food group; and vitamins and minerals rich food groups such as vegetables group and fruit group; and sugar food group intake in a week. Overall, in all these five food categories or groups mentioned above, more than $40 \%$ of the participants reported a low intake in a week. Nation-wide data on dietary intake and patterns are not available in Cameroon for women of childbearing age. Dietary patterns are population specific, since they are influenced by sociocultural factors and food availability [22]. The observation made in this study has earlier been stated whereby, Cameroonian eating habits is mainly characterized by low 
fruits and vegetables consumption, added to the higher consumption of foods rich in starch and sugar [23]. As earlier shown, in the present study, dietary habits are mostly characterized by cereals and tubers like rice, maize, cassava, corn fufu ... showing that carbohydrate rich food serve as the major source of energy among the majority of women of the study. Similar findings were found in a study in Nepal among women of childbearing age [24]. The main reason for the lack of a balanced diet in the food habits of women of the study population could be that there is a considerable lack of nutritional knowledge regarding healthy dietary patterns and habits by most women. According to Nkengfack et al., studies show that nutritional knowledge in Cameroon is lacking [25]. A healthy diet must be balanced not only in terms of macronutrients content (intake of proteins, carbohydrates and fats), but also in terms of micronutrients intake (vitamins and mineral) [22]. The need for maintaining optimal food habits throughout a woman's lifetime is essential to optimize her health and that of her offspring [8].

This study revealed that the nutritional status of women of childbearing age in the study is poor in general. Our analysis reveals that, a considerate percentage of the study participants were obese (38.5\%), 30.8\% overweight, $2.1 \%$ underweight and $28.6 \%$ of them had a normal weight status. A mother's nutritional status before pregnancy can affect reproduction and pregnancy outcomes, and pre-pregnancy weight is a common indicator of a woman's nutritional status [26]. Nutritional status is an important aspect of health and wellness before and during pregnancy. The prevalence of underweight $(2.1 \%)$ was lower than that reported by WHO, in Cameroon among women of childbearing age which was $6.9 \%$ [6]. This percentage is equally lower than that observed in the 2004 demographic and health survey (DHS) [27] and 2011 DHS [28] carried out in Cameroon which found a prevalence rate of $7 \%$ and $8 \%$ respectively of underweight among women of childbearing age. While that of obesity (38.5\%) was higher than the proportions observed in the same DHSs which were $29.40 \%$ in 2004 as compared to $32.17 \%$ in 2011 for obesity [27] [28], making an increase of $2.77 \%$ between 2004 and 2011 [14]. These percentages show that the prevalence of underweight among reproductive women in Cameroon is on the decrease while that of obesity is on the rise. In a 2017 WHO report, Cameroon has been cited among the countries in WHO African regions with the lowest rates of maternal underweight [6]. Also, the above results show that despite the high prevalence of pre-pregnancy overweight and obesity in this population, the prevalence of women who are underweight before pregnancy still persists in Cameroon. Under nutrition in women has been shown to contribute to 20 percent of maternal deaths, and is a significant risk factor for stillbirths, preterm births, small for gestational age and low birth weight babies [2]. Our findings also showed that, the rate of obesity increased with age and its prevalence was highest in the 41 49 years age group; the rate of overweight was the highest in the 31 - 40 years age group. Also, all the age groups were found to be risk factors of obesity, with women in the 41 - 49 years age group 9.568 times most likely of becoming obese. 
A recent study also found that overweight and obesity increased with maternal age among women of childbearing age in Cameroon [29].

The northwest region showed the highest prevalence of underweight and overweight and it was equally observed that participants living in this region were less likely of becoming obese. The rates of obesity was highest in the western region, the latter showing the next highest rates after the northwest region. The prevalence of overweight and obesity in this study were higher than those observed in a study which used the database of the 1998, 2004 and 2011 DHSs in Cameroon [30]. The fact that the northwest and west regions recorded the highest prevalence of poor nutritional status, could be linked to their dietary habits. The northwest and the west regions also called the grass fields, are zones of Cameroon that have humid and wet climates, influencing natural food resources and dietary habits. Tubers are available all year round in these regions, bean species are the main sources of plant protein [25] and as stated, beans is usually eaten with a cereal such as rice in the North West region [31]. Tubers, and fufu made from some tubers are often consumed in these regions which provide the bulk of energy in the diets. In addition, many of the traditional soups and dishes of these regions, contain large amounts of palm oil, the basic fat used in the Cameroonian kitchen [32]. Tubers and palm oil which are energy dense but poor in nutrients are usually eaten with small amounts of vegetables which provide little amounts of micronutrients. Therefore, the energy dense and low micronutrients content of most diets coupled to the lack of dietary diversification in these regions might be reasons for the high prevalence of overweight and obesity. Also a limited nutrition knowledge stated as possible reason for unhealthy dietary patterns among university students in the North West region in a study carried out in Cameroon [31], could also account for the high prevalence of all forms of malnutrition in these two regions.

Higher rates of overweight and obesity were associated to a primary educational level. Housewives and married women recorded the highest numbers of underweights, obese and overweight participants. Also, married women were more likely of becoming obese. The high level of overweight and obesity among women with a primary educational level is consistent with a finding made in Cameroon which showed that women aged 15 - 49 years in Cameroon with a primary educational level were 1.47 times more likely to be overweight [14]. The fact that pre-pregnancy poor nutritional status were associated to no or low educational levels (illiteracy, primary educational level and secondary level) may be due to the lack of finances to get access to quality and diversified foods such as fruits, rich in micronutrients, low in calories and saturated fatty acids that enhance better micronutrient status and prevent weight gain. Another possible explanation to these high rates of malnutrition among women with no educational level and those with a low level could be the lack of nutritional knowledge. Studies have pointed out the positive association of a high educational level of the mother and increased good attitudes towards healthy eating habits [33] [34]; and the association between nutritional education among illiterate mothers and 
good knowledge about dietary practices during pregnancy in Nigeria [35].

The frequent intake of cereals and tubers which are carbohydrate rich foods, was associated to higher rates of underweight, overweight and obesity while a low intake of pulses; milk \& dairy products (proteins rich foods); vegetables and fruits food groups (vitamins and minerals rich foods) in a week were all associated to higher rates of underweight, overweight and obesity. Optimum intake of food sources of various micronutrients are known to prevent deficiencies. Under nutrition, occur due to insufficient intake or even sufficient intakes combined with impaired absorption due to infection, disease, or inflammation [36]. These various mechanisms may explain the association between higher rates of underweight and low intakes of various food sources. However, the higher levels of all forms of malnutrition in association to frequent intake of cereals \& tubers group in this study, may be related to the high energy and low micronutrients content of food items of this food group.

\section{Limitation of the Study}

Limitation includes self-reporting of data by participants; which made dietary assessment difficult to appreciate.

\section{Conclusion and Recommendations}

This study revealed that in general, women of childbearing age of the study had an unhealthy dietary pattern mostly frequent in carbohydrate rich foods such as cereals and tubers, and foods rich in fats and oils but infrequent in proteins rich foods, and vitamins and minerals rich foods such as vegetables and fruits. The assessment of the nutritional status revealed that in general, most study participants had a poor nutritional status. A few of the study participants were underweight $(2.1 \%)$. High rates of overweight and obesity were observed and were found to increase with age and these rates were higher in some regions (northwest and western regions) compared to other regions suggesting that nutrition interventions should be age and region specific. Low educational levels were associated to higher prevalence of underweight, overweight and obesity suggesting the need for nutritional education to improve the knowledge of these women on good nutritional practices. Also, the low intake of most food groups was linked to higher levels of underweight, overweight and obesity suggesting the need to emphasize on the consumption of proteins rich foods, and vitamins and minerals rich foods such as vegetables and fruits to improve nutritional status. In addition, the frequent consumption of vegetables and fruits rich in micronutrients and low in energy should be encouraged in order to fight both extremes of malnutrition among women of childbearing age in these regions of Cameroon.

\section{Acknowledgements}

The authors are thankful to all the study participants for taking part in this research study. 


\section{Consent for Publication}

Not applicable.

\section{Availability of Data and Materials}

Data and materials used in this study are available on reasonable request.

\section{Funding}

This study was sponsored by the J \& A Oben Foundation.

\section{Authors' Contributions}

CMM, JLN, and BGKA conceived and designed the study. CMM, BRTT and MWN collected data and performed laboratory tests. CMM, FRN and BGKA carried out the statistical analysis. CMM, BGKA drafted the manuscript. JEO supervised the study. All authors read and approved the final manuscript.

\section{Conflicts of Interest}

The authors declare that there is no conflicts of interest regarding the publication of this paper.

\section{References}

[1] Ramage, S.M., McCargar, L.J., Berglund, C., Harber, V., Bell, R.C. and the APrON Study Team (2015) Assessment of Pre-Pregnancy Dietary Intake with a Food Frequency Questionnaire in Alberta Women. Nutrients, 7, 6155-6166. https://doi.org/10.3390/nu7085277

[2] Dean, S.V., Lassi, Z.S., Imam, A.M. and Bhutta, Z.A. (2014) Preconception Care: Nutritional Risks and Interventions. Reproductive Health, 11, Article No. S3. http://www.reproductive-health-journal.com/content/11/S3/S3 https://doi.org/10.1186/1742-4755-11-S3-S3

[3] Triunfo, S. and Lanzone, A. (2015) Impact of Maternal under Nutrition on Obstetric Outcomes. Journal of Endocrinological Investigation, 38, 31-38. https://doi.org/10.1007/s40618-014-0168-4

[4] United Nations Children's Fund (UNICEF) (2013) Improving Child Nutrition the Achievable Imperative for Global Progress. http://www.unicef.org/publications/index.html

[5] Stephenson, J., Heslehurst, N., Hall, J., Schoenaker, D.A.J.M., Hutchinson, J., Cade, J.E., Poston, L., Barrett, G., Crozier, S.R., Barker, M., Kumaran, K., Yajnik, C.S., Baird, J. and Mishra, G.D. (2018) Preconception Health 1, before the Beginning: Nutrition and Lifestyle in the Preconception Period and Its Importance for Future Health. The Lancet, 391, 1830-1841. https://doi.org/10.1016/S0140-6736(18)30311-8

[6] World Health Organization (WHO) (2017) Nutrition in the WHO African Region. Brazzaville: World Health Organization. Licence: CC BY-NCSA 3.0 IGO. https://www.afro.who.int

[7] Sun, J., Buys, N.J. and Hills, A.P. (2014) Dietary Pattern and Its Association with the Prevalence of Obesity, Hypertension and Other Cardiovascular Risk Factors among 
Chinese Older Adults. International Journal of Environmental Research and Public Health, 11, 3956-3971. https://doi.org/10.3390/ijerph110403956

[8] Bartley, K.A., Underwood, B.A. and Deckelbaum, R.J. (2005) A Life Cycle Micronutrient Perspective for Women's Health. The American Journal of Clinical Nutrition, 81, 1188S-1193S. https://doi.org/10.1093/ajcn/81.5.1188

[9] Dunneram, Y. and Jeewon, R. (2015) Healthy Diet and Nutrition Education Program among Women of Reproductive Age: A Necessity of Multilevel Strategies or Community Responsibility. Health Promotion Perspectives, 5, 116-127. https://doi.org/10.15171/hpp.2015.014

[10] Galtier, F., Raingeard, I., Renard, E., Boulot, P. and Bringer, J. (2008) Optimizing the Outcome of Pregnancy in Obese Women: From Pregestational to Long-Term Management. Diabetes and Metabolism, 34, 19-25.

https://doi.org/10.1016/j.diabet.2007.12.001

[11] Dapi, L.N., Hornell, A., Janlert, U., Stenlund, H. and Larsson, C. (2011) Energy and Nutrient Intakes in Relation to Sex and Socio-Economic Status among School Adolescents in Urban Cameroon, Africa. Public Health Nutrition, 14, 904-913. https://doi.org/10.1017/S1368980010003150

[12] Ponka, R. and Fokou, E. (2011) Dietary Intake, Zincemia and Cupremia of Cameroonian School Children of Ngali II. International Journal of Food Science and $\mathrm{Nu}$ trition, 62, 377-384. https://doi.org/10.3109/09637486.2010.550274

[13] Engle-Stone, R., Ndjebayi, A.O., Nankap, M., Killilea, D.W. and Brown, K.H. (2014) Stunting Prevalence, Plasma Zinc Concentrations, and Dietary Zinc Intakes in a Nationally Representative Sample Suggest a High Risk of Zinc Deficiency Among Women and Young Children in Cameroon. The Journal of Nutrition, 144, 382-391. https://doi.org/10.3945/jn.113.188383

[14] Yongsi, H.B.N. and Ngwa, O.A. (2015) Trends and Risks Factors Associated to Women Obesity in Cameroon and Gabon. American Journal of Health Research, 2 , 420-428. https://doi.org/10.11648/j.ajhr.20140206.26

[15] Mphoweh, J.N. and Futonge, N.K. (2009) Regions of Cameroon. http://www.cameroon-tour.com/

[16] Magnani, R. (1997) Sampling Guide: IMPACT Food Security and Nutrition Monitoring Project. ISTI Arlington, VA. https://www.alnap.org

[17] United Nations Children's Fund (UNICEF) (1995) Monitoring Progress toward the goals of the World Food Summit for Children: A Practical Handbook for Multiple Indicator Surveys. New York, NY 10017.

[18] World Health Organization (WHO) (2009) WHO STEPS Instrument Question by Question. http://www.who.int/chp/steps/STEPS QbyQ Guide.pdf

[19] Wiesmann, D., Bassett, L., Benson, T. and Hoddinott, J. (2009) Validation of the World Food Programme's Food Consumption Score and Alternative Indicators of Household Food Security. IFPRI Discussion Paper. Washington, DC. http://www.ifpri.org/cdmref/p15738coll2/id/32010/filename/32011.pdf

[20] Kabunga, N., Ghosh, S. and Griffiths, J.K. (2014) Can Smallholder Fruit and Vegetable Production Systems Improve Household Food Security and Nutritional Status of Women? Evidence from Rural Uganda. Development Strategy and Governance Division. IFPRI Discussion Paper 01346. https://doi.org/10.2139/ssrn.2483967

[21] World Health Organization (WHO) (2000) Obesity: Preventing and Managing the Global Epidemic.

http://www.who.int/nutrition/publications/obesity/WHO TRS 894/en/ 
[22] Cetin, I. and Laoreti, A. (2015) The Importance of Maternal Nutrition for Health. Journal of Paediatric and Neonatal Individualized Medicine, 4, e040220.

[23] Echouffo-Tcheugui, J.B. and Kengne, A.P. (2011) Chronic Noncommunicable Diseases in Cameroon: Burden, Determinants and Current Policies. Globalization and Health, 7, 44. http://www.globalizationandhealth.com/content/7/1/44

[24] Bhandari, S., Sayami, J.T., Thapa, P., Sayami, M., Kandel, B.P. and Banjara, M.R. (2016) Dietary Intake Patterns and Nutritional Status of Women of Reproductive Age in Nepal: Findings from a Healthy Survey. Archives of Public Health, 74, Article No. 2. https://doi.org/10.1186/s13690-016-0114-3

[25] Nkengfack, G.N.S., Torimiro, J.N., Ngogang, J. and Englert, H. (2011) A Review of Nutrition in Cameroon: Food Supply, Factors Influencing Nutritional Habit and Impact on Micronutrient (Vitamin A, Iodine, Iron) Status. Health Science and Disease, 12, 1-11.

[26] Ward, E.M. and Siega-Riz, A.M. (2012) Maternal Nutrition. http://www.meadjohnson.com/pediatrics/us-en/sites/hcp-usa/files/LB2882-Materna l-Nutrition-Monograph-2 1.pdf

[27] Demographic and Health Survey (DHS) and National Institute of Statistics (NIS) (2004) Demographic and Health Survey of Cameroon. http://www.dhsprogram.com/pubs/pdf/FR163/FR163-CM04.pdf

[28] National Institute of Statistics (NIS) and ORC Macro (2011) Demographic and Health Survey of Cameroon.

http://www.cnls.cm/docs/Rapport EDS 2011 au Cameroun.pdf

[29] Engle-Stone, R., Nankap, M., Ndjebayi, A.O., Friedman, A., Tarini, A., Brown, K.H. and Kaiser, L. (2018) Prevalence and Predictors of Overweight and Obesity among Cameroonian Women in a National Survey and Relationships with Waist Circumference and Inflammation in Yaoundé and Douala. Maternal and Child Nutrition, 14, e12648. https://doi.org/10.1111/mcn.12648

[30] Amugsi, D.A., Dimbuene, Z.T., Mberu, B., Muthuri, S. and Ezeh, A.C. (2017) Prevalence and Time Trends in Overweight and Obesity among Urban Women: An Analysis of Demographic and Health Surveys Data from 24 African Countries, 1991-2014. BMJ Open, 7, e017344.

https://www.ncbi.nlm.nih.gov/pmc/articles/PMC5665233

https://doi.org/10.1136/bmjopen-2017-017344

[31] Niba, L.L., Atanga, M.B. and Navti, L.K. (2017) A Cross Sectional Analysis of Eating Habits and Weight Status of University Students in Urban Cameroon. BMC Nutrition, 3, Article No. 55. https://doi.org/10.1186/s40795-017-0178-7

[32] Mennen, L.I., Mbanya, J.C., Cade, J., Balkau, B., Sharma, S., Chungong, S. and Cruickshank, J.K. (2000) The Habitual Diet in Rural and Urban Cameroon. European Journal of Clinical Nutrition, 54, 150-154.

https://doi.org/10.1038/sj.ejcn.1600909

[33] Al-Shookri, A., Al-Shukaily, L., Hassan, F., Al-Sheraji, S. and Al-Tobi, S. (2011) Effect of Mothers Nutritional Knowledge and Attitudes on Omani Children's Dietary Intake. Oman Medical Journal, 26, 253-257. https://doi.org/10.5001/omj.2011.61

[34] Yabanc1, N., Kısaç, İ. and Karakuş, S.Ş. (2014) The Effects of Mother's Nutritional Knowledge on Attitudes and Behaviors of Children about Nutrition. Procedia-Social and Behavioral Sciences, 116, 4477-4481.

https://doi.org/10.1016/j.sbspro.2014.01.970

[35] Kever, R.T., Martins, S.D., Lola, N., Dathini, H., Habu, H., Fatima, A.A. and Sambo, B.D. (2015) Knowledge and Attitude of Pregnant Women towards Dietary Practices 
in Yerwa Clinic, Maiduguri Metropolitan Council; Borno State. Journal of Research in Nursing and Midwifery, 4, 12-19.

[36] Bailey, R.L., West, K.P. and Black, R.E. (2015) The Epidemiology of Global Micronutrient Deficiencies. Annals of Nutrition and Metabolism, 66, 22-33.

https://doi.org/10.1159/000371618 
Appendix: Questionnaire

NUTRITION AND HEALTH STUDY

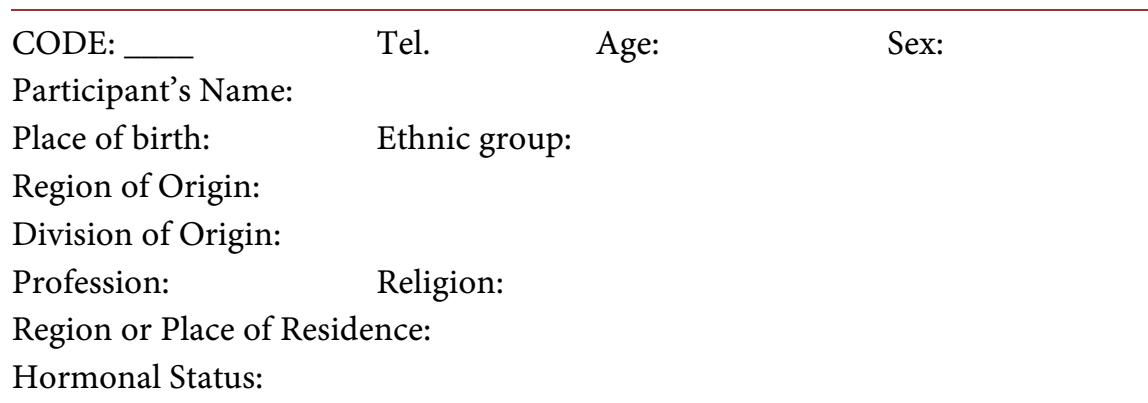

PARAMETERS OF INTEREST:

Weight (kg):

BMI $\left(\mathrm{kg} / \mathrm{m}^{2}\right)$ :

Waist circumference $(\mathrm{cm})$ :

SBP /DBP mm Hg:

FC.
Height (m):

$\%$ Body fat:

Hip circumference $(\mathrm{cm})$ :

\section{A) DIETARY HABITS AND HEALTH STATUS}

1) How many times do you usually eat per day?

Number of times/day

2) At which time/moment of the day do you eat?

3) Do you cook your meals yourself?
Always/Often;
Occasionally/Sometimes;
Rarely/Never

3a) Who cooks your meals?

4) Do you sometimes eat out of the house?

$$
\text { Yes } 4 \mathrm{a}, 4 \mathrm{~b} \quad \text { No } 5
$$

4a) When you eat out of the house, where do you generally eat? (Several answers are possible)

$\begin{array}{lll}\text { VIP Restaurant; } & \text { Restaurant; } & \text { mama put } \\ \text { Road; } & \text { Work/ canteen of the company; } & \text { Cafeteria }\end{array}$

$4 \mathrm{~b})$ For what reason(s) do you eat out of the house? (Several answers are possible)

$\square$ Work place far away from the house; $\square$ For pleasure

$\square$ Nothing to eat in the house; $\square$ Other reasons (precise)

5) During the last 7 days, did you eat out of the house? $\square$ No $\square$ Yes

5a) How many days in the week? Nber of days/week

How many times these days Nber of times /day

6) During the last 7 days, did you buy cooked food in the street? $\square$ No $\square$ Yes

6a) How many days in the week? Nber of days/week

How many times these days? Nber of times /day 7 During the last 7 days, did you eat in a resturant? $\square$ No $\square$ Yes

7a) How many days in the week? Nber of days/week

How many times these days? Nber of times/day 
8) During the last 7 days, did you eat in a mama put?

$\square$ No $\square$ Yes

8a) How many days in the week? Nber of days/week How many times these days? Nber of times /day

9) During the last 7 days, did you eat in a canteen of a company? No $\square$ Yes

9a) How many days in the week? How many times these days? Nber of days/week __ Nber of times /day

10) During the last 7 days, did you eat in a cafeteria $\square$ No $\square$ Yes 10a) How many days in the week? How many times these days? Nber of days/week Nber of times /day

11)-13) Refer to the food frequency questionnaire in the form of a table below to answer questions with respect to your food habits during the last seven days. Please tick all possible answers.

14) Do you consider that you eat too much sugar for your health? $\square$ Yes $\square$ No $\square$ undecided

15) Do you consider that you eat too much fat and oils for your health? $\square$ Yes $\square$ No $\square$ undecided

16) Do you consider that you eat too much salt for your health? $\square$ Yes $\square$ No $\square$ Undecided

17) Do you consider that you eat too much for your health?

$\square$ Yes $\square$ No $\square$ Undecided

18) Do you consider that by changing your way of eating you can ameliorate your health? $\square$ Yes $\square$ No $\square$ Undecided

19) Compared to other women of your age, you would say that your usual food/diet is ...

Very good; $\square$ Good; $\square$ Fairly good; $\square$ Bad; $\square$ Undecided

20) Compared to other women of your age you would say that your health is in general ...

Very good $\square$ Good $\square$ Fairly good $\square$ Bad $\square$ Undecided

20a) Do you have any disabilities $\square$ Yes $\square$ No

20b) If yes, please specify

21) Do you receive information on diet? $\square$ Yes $\square$ No

21a) If yes, by which means do you receive information on diet (several answers are possible)

$\square$ Radio $\square$ Television $\square$ Newspapers, review or brochures

$\square$ Books or courses $\square$ Health professionals (doctors, dietetics, nurses)

$\square$ Others (precise)

21b) Would you like to receive information on diets/foods? $\square$ Yes $\square$ No

21c) By which means would you like to receive information on diets/foods (several answers are possible): $\square$ Radio $\square$ Television $\square$ Newspapers, review or brochures

$\square$ Books or courses $\square$ Health professionals (doctors, dietetics, nurses) $\square$ Others (precise)

22) Do you currently follow a particular diet for your health? $\square$ No $\square$ Yes 
22a) For which reason do you follow this diet? Specify

23) In your household, are they any foods which are prohibited to you? $\square$ No $\square$ Yes

23a) If Yes, Which?

23b) Why are these foods prohibited?

24) Do you take any dietary supplements $\square$ Yes $\square$ No

24a) If yes, which supplements?

24b) For what reasons do you take them?

25) As a woman of childbearing age, are you presently pregnant? $\square$ Yes $\square$ No

25a) If yes, what is the age of your pregnancy?

25b) If No, when was your last pregnancy? months/ years

25c) How many pregnancies have you carried to the end Number of full-term pregnancies

25d) Are you a breastfeeding/lactating mother? $\square$ Yes $\square$ No

\section{B) INFORMATION ON AREA/REGION OF RESIDENCE (URBANISATION)}

26) Where were you born? Specify the place of birth:

$\square$ Rural area; $\square$ Secondary city /little city; $\square$ Big city

26a) How long have you lived in your place of birth? Specify:

27) For how long have you continuously lived in the current region? Years

27a) Previously, where did you live?

$\square$ Does not apply (has always lived in region or area of residence since birth)

$\square$ Big city; $\square$ Other secondary city; $\square$ In the village /Rural area; $\square$ Abroad: (Specify)

27b) For how long have you lived in the current place? Years

28) For which reason(s) do you now live here? Specify

C) SOCIO-ECONOMIC INFORMATIONS

29) What is your current matrimonial status? $\square$ Married or lives with a partner; $\square$ widow, divorced, separated; $\square$ single/Fiancé, lives alone

30) In which type of household do you live? $\square$ Monogamous $\square$ polygamous

31) What is the gender of the head of the family? $\square$ Male $\square$ Female

32) What is your highest level of education?

$\square$ No schooling or illiterate

$\square$ Literate; $\square$ Primary

$\square$ First cycle secondary education (1st cycle, Form 1 to 5)

$\square$ Second cycle and Professional school

$\square$ University

33) What is your main source of revenue?

$\square$ Salary (permanent employment)

$\square$ Salary (daily or temporal)

$\square$ Business; $\square$ Help, assistance; $\square$ Partner

$\square$ Other

34) Have you worked or exerted a business or any activity that generated money 
during the last 12 months? $\square$ No $\square$ Yes

34a) If yes, For how long have you worked during this period? Number of months

34b) What was your main job? Give all possible details

35) What is the main source of revenue of your partner?

36) What is the total number of people in your household (Including you)? Number of women of child bearing age 15 to 49 years; Number of women aged above 49 years; Number of men aged above 15 years; Number of adolescents ( $12 \leq$ years $\leq 15)$; Number of children (<12 year)

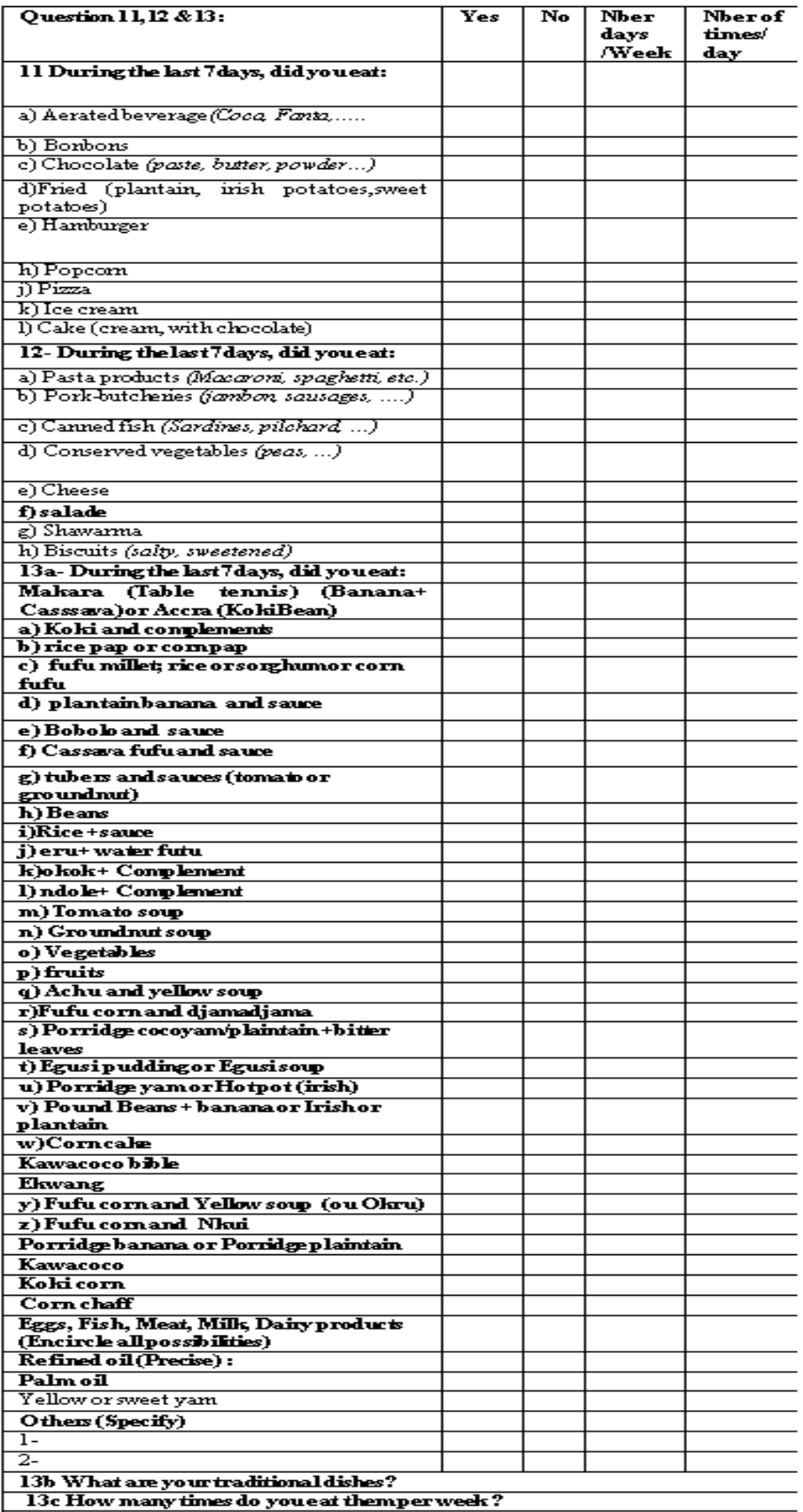

